УДК 615.014.47:615.453.6:582.752:581.135.5

DOI https://doi.org/10.11603/2312-0967.2019.3.10444

\title{
ОБҐРУНТУВАННЯ ВИБОРУ ДОПОМІЖНИХ РЕЧОВИН ДЛЯ ОДЕРЖАННЯ ТАБЛЕТОК З РОСЛИННИМИ ЕКСТРАКТАМИ ТА ЕФІРНОЮ ОЛІЄЮ
}

\section{О. І. Гордієнко, Т. А. Грошовий}

\author{
Тернопільський національний медичний університет імені І. Я. Горбачевського \\ мОЗ України \\ hordiienko.oi@gmail.com
}

\section{ІНФОРМАЦІЯ}

Надійшла до редакції / Received: 28.08.2019

Після доопрацювання / Revised: 12.09.2019

Прийнято до друку / Accepted: 17.09.2019

\section{Ключові слова:}

таблетки;

рослинні екстракти; допоміжні речовини; фрармако-технологічні показники; математичне планування.

\begin{abstract}
АНОТАЦІЯ
Мета роботи. Дослідити та обрати оптимальні допоміжні речовини (ДР) в склад таблеток на основі сухих екстрактів трави герані криваво-червоної, герані сибірської та ефрірної олії шавлії мускатної для місцевого застосування в ротовій порожнині.

Матеріали і методи. У склад таблеток входить фрармацевтична композиція, що містить сухі екстракти трави герані криваво-червоної і герані сибірської, ефірну олію шавлії мускатної, а також ДР. Вплив ДР на фрармако-технологічні властивості таблеток вивчали за показниками: процес пресування, зовнішній вигляд, однорідність маси, стійкість до роздавлювання, стираність, час розпадання.

Результати й обговорення. Результати дисперсійного аналізу експериментальних даних показали, що процес пресування таблеток із МКЦ 102, натрію кроскармелозою та неуселіном UFL 2 проходив рівномірно, без адгезії порошкових мас до прес-інструмента

Таблетки із неусиліном UFL 2, компактролом, Ді-Пак і просолвом SMCC 90 мали найкращий зовнішній вигляд.

Однорідність маси таблеток в межах \pm 5 \% забезпечували наступні ДР: компактрол, емкомпрес, крохмаль кукурудзяний і прежелатинізований, натрію стеарилсрумарат, магнію карбонат основний, МКЦ 102, манітол 60. Найміцніші таблетки отримували з допомогою неуселіну US 2, MКЦ 200, натрію карбоксиметилкрохмалю, мікроцелаку 100, Ді-Пак і магнію стеарату.

Неусилін UFL 2, емкомпрес, МКЦ 102, крохмаль прежелатинізований, лудіпрес і кислота стеаринова дозволили отримати таблетки із найменшою стираністю, а найшвидше розпадались таблетки із натрію кроскармелозою, аеросилом 200, МКЦ бурстом, манітолом 60, емкомпресом і натрію стеарилфумаратом.

Висновки. Вивчено вплив 30-ти ДР на фрармако-технологічні показники таблеток 3 рослинними екстрактами та ефірною олією. За сукупністю вивчених показників відібрано кращі поєднання ДР для подальшого вивчення з метою розробки оптимального складу та технології таблеток для місцевого застосування у ротовій порожнині.
\end{abstract}

Вступ. Лікування рослинами та фрітозасобами склало екзамен часом і тепер визнані в медицині по всьому світу. Їхньою значною перевагою, на противагу синтезованим лікарським засобам (ЛЗ), є наяв-

ISSN 2312-0967. Pharmaceutical review. 2019. № 3 
Фармацевтична технологія, біофармація, гомеопатія Pharmaceutical technology, biopharmacy, homeopathy

ність природного комплексу біологічно активних речовин (БАР) у найбільш доступних та легкозасвоюваних формах.

Як джерело комплексу БАР, цікавим об'єктом дослідження $€$ лікарська рослинна сировина (ЛРС) роду Geranium, а саме трава герані сибірської і герані криваво-червоної. У композиції з ефрірною олією шавлії мускатної сухі екстракти трави обох видів гераней проявляють антибактеріальну, протигрибкову і протизапальну дію [1]. Дану фрармацевтичну композицію у вигляді таблеток можна використовувати для місцевого лікування захворювань ротової порожнини. А щоб забезпечити даний терапевтичний ефект та усі фрармако-технологічні характеристики таблеток, необхідно правильно підібрати ДР, що і $є$ метою нашої роботи.

Матеріали і методи. Діючі речовини, що входять у склад таблеток - це сухі екстракти трави герані кри-

\section{Таблиця 1}

Допоміжні речовини, які вивчали в процесі розробки складу таблеток для місцевого застосування у ротовій порожнині методом прямого пресування

\begin{tabular}{|c|c|}
\hline Фактори & Рівні фракторів \\
\hline$A$ - сорбенти & $\begin{array}{l}a_{1}-\text { аеросил } 200 \\
a_{2}-\text { аеросил } 380 \\
a_{3}-\text { неуселін UFL } 2 \\
a_{4}-\text { неуселін US } 2 \\
a_{5}-\text { магнію карбонат основний }\end{array}$ \\
\hline B - наповнювачі & $\begin{array}{l}b_{1}-\text { МКЦ } 102 \\
b_{2}-\text { МКЦ } 200 \\
b_{3}-\text { просолв SMCC } 90 \\
b_{4}-\text { просолв EASYtab SP } \\
b_{5}-\text { МКЦ бурст }\end{array}$ \\
\hline C - розпушувачі & $\begin{array}{l}c_{1}-\text { крохмаль кукурудзяний } \\
c_{2}-\text { натрію кроскармелоза } \\
c_{3}-\text { натрію карбоксиметилкрохмаль } \\
c_{4}-\text { натрію крохмальгліколят } \\
c_{5}-\text { крохмаль прежелатинізований }\end{array}$ \\
\hline$D-$ цукри & $\begin{array}{l}d_{1}-\text { манітол } 60 \\
d_{2}-\text { перлітол } 500 \mathrm{DC} \\
d_{3}-\text { лудіпрес } \\
d_{4}-\text { мікроцелак } 100 \\
d_{5}-\text { перлітол } 100 \mathrm{SD}\end{array}$ \\
\hline$E-$ ковзні речовини & $\begin{array}{l}e_{1}-\text { кальцію гідрофоосфат безводний } \\
e_{2}-\text { компактрол (кальцію сульфат дигідрат) } \\
e_{3}-\text { емкомпрес (кальцію гідрофроссрат дигідрат) } \\
e_{4}-\text { МагГран (магнію оксид гранульований) } \\
e_{5}-\text { Ді-Пак (сахароза+мальтодекстрин) }\end{array}$ \\
\hline$F-$ змащувальні речовини & $\begin{array}{l}f_{1}-\text { магнію стеарат } \\
f_{2}-\text { кальцію стеарат } \\
f_{3}-\text { кислота стеаринова } \\
f_{4}-\text { натрію стеарилфумарат } \\
f_{5}-\text { натрію лаурилсульфрат }\end{array}$ \\
\hline
\end{tabular}

ваво-червоної і герані сибірської, а також ефрірна олія шавлії мускатної у співвідношенні - 3:1:1,2 [1]. Крім рослинних екстрактів і ефрірної олії, у склад таблеток входили ДР вітчизняного та зарубіжного виробництва [2], яких для експерименту обрано 30 (табл. 1).

Порошкові маси готували за класичною схемою виробництва багатокомпонентних таблеток, що містять сухі екстракти та досліджували їх фрармако-технологічні властивості, а саме насипну густину $\left(\mathrm{y}_{1}\right)$, густину після усадки $\left(\mathrm{y}_{2}\right)$, текучість $\left(\mathrm{y}_{3}\right)$, кут природнього укосу $\left(\mathrm{y}_{4}\right)[3,4]$. Після цього порошкові маси пресували на лабораторній таблетній машині 3 середньою масою таблетки 0,25 г та досліджували процес пресування $\left(\mathrm{y}_{5}\right)$, зовнішній вигляд таблеток $\left(\mathrm{y}_{6}\right)$, однорідність маси $\left(\mathrm{y}_{7}\right)$, стійкість до роздавлювання $\left(\mathrm{y}_{8}\right)$, стираність $\left(\mathrm{y}_{9}\right)$ і час розпадання $\left(\mathrm{y}_{10}\right)$ [4].

В якості плану експерименту використовували 5х5 гіпер-греко-латинський квадрат четвертого порядку [5]. Матриця планування експерименту та результати 
Фармацевтична технологія, біофармація, гомеопатія Pharmaceutical technology, biopharmacy, homeopathy

дослідження наведено в таблиці 2. Отримані результати підлягали дисперсійному аналізу за схемою шестиоракторного експерименту [5].

Результати й обговорення. Попередні результати за показниками насипної густини, густини після усадки, текучості і кута природного укосу порошкових мас для таблетування вказують на можливість отри- мання таблеток методом прямого пресування [3]. Порошкові маси для таблетування пресували та оцінювали даний процес за 5-бальною шкалою, згідно якої групи ДР у ранжованому ряду розмістились у такому порядку: B (C) > A > D (E) > F. У даному випадку значущими є тільки три фрактори, а саме: наповнювачі, розпушувачі, сорбенти. Найкращим на-

\section{Таблиця 2}

Матриця планування експерименту та результати дослідження таблеток із екстрактами трави герані сибірської, герані криваво-червоної та ефрірної олії шавлії мускатної

\begin{tabular}{|c|c|c|c|c|c|c|c|c|c|c|c|c|c|c|c|c|c|c|c|c|}
\hline $\begin{array}{l}\text { № } \\
\text { ce- } \\
\text { piï }\end{array}$ & $A$ & $B$ & C & D & $\mathrm{E}$ & $F$ & $y_{5}$ & $y_{5}$ & $\mathrm{y}_{6}$ & $\mathrm{y}_{6}$ & $y_{7}$ & $y_{7}$ & $\mathrm{y}_{8}$ & $\mathrm{y}_{8}$ & $\mathrm{y}_{9}$ & $y_{9}$ & $y_{10}$ & $y_{10}$ & D & $\mathrm{D}^{\prime}$ \\
\hline & $a_{1}$ & $b_{1}$ & $\mathrm{C}_{1}$ & $\mathrm{~d}_{1}$ & $\mathrm{e}_{1}$ & $f_{1}$ & 5 & 4 & 4 & 3 & 4,48 & 4,32 & 55 & 56 & 1,18 & 1,15 & 3,7 & 2,9 & 0,583 & 0,524 \\
\hline 2. & $a_{1}$ & $b_{2}$ & $\mathrm{C}_{2}$ & $\mathrm{~d}_{2}$ & $\mathrm{e}_{2}$ & $f_{2}$ & 5 & 4 & 3 & 4 & 6,30 & 5,96 & 82 & 88 & 2,27 & 2,26 & 0,4 & 0,6 & 0 & 0 \\
\hline 3. & $a_{1}$ & $b_{3}$ & $\mathrm{C}_{3}$ & $\mathrm{~d}_{3}$ & $\mathrm{e}_{3}$ & $\mathrm{f}_{3}$ & 5 & 4 & 3 & 3 & 5,39 & 4,88 & 75 & 79 & 0,24 & 0,25 & 1,1 & 1,9 & 0,856 & 0,742 \\
\hline 4. & $a_{1}$ & $b_{4}$ & $\mathrm{C}_{4}$ & $\mathrm{~d}_{4}$ & $\mathrm{e}_{4}$ & $\mathrm{f}_{4}$ & 3 & 3 & 3 & 2 & 5,97 & 5,46 & 26 & 27 & 6,20 & 6,17 & 0,1 & 0,2 & 0 & 0 \\
\hline 5. & $a_{1}$ & $b_{5}$ & $c_{5}$ & $\mathrm{~d}_{5}$ & $\mathrm{e}_{5}$ & $f_{5}$ & 3 & 3 & 2 & 3 & 6,25 & 5,76 & 34 & 40 & 1,96 & 1,94 & 3,0 & 3,3 & 0 & 0 \\
\hline 6. & $a_{2}$ & $b_{1}$ & $\mathrm{C}_{2}$ & $\mathrm{~d}_{3}$ & $\mathrm{e}_{4}$ & $f_{5}$ & 5 & 4 & 3 & 3 & 7,20 & 6,81 & 76 & 79 & 0,53 & 0,50 & 0,7 & 0,8 & 0,497 & 0,565 \\
\hline 7. & $a_{2}$ & $b_{2}$ & $\mathrm{C}_{3}$ & $\mathrm{~d}_{4}$ & $e_{5}$ & $f_{1}$ & 4 & 4 & 4 & 4 & 6,51 & 6,02 & 186 & 191 & 0,38 & 0,32 & 12,3 & 14,3 & 0,683 & 0,698 \\
\hline 8. & $a_{2}$ & $b_{3}$ & $\mathrm{C}_{4}$ & $\mathrm{~d}_{5}$ & $e_{1}$ & $\mathrm{f}_{2}$ & 3 & 3 & 3 & 4 & 8,14 & 7,85 & 67 & 71 & 2,58 & 2,52 & 6,2 & 5,2 & 0 & 0 \\
\hline 9. & $a_{2}$ & $b_{4}$ & $\mathrm{C}_{5}$ & $\mathrm{~d}_{1}$ & $\mathrm{e}_{2}$ & $\mathrm{f}_{3}$ & 5 & 4 & 4 & 3 & 4,88 & 4,22 & 117 & 119 & 0,21 & 0,25 & 8,6 & 8,8 & 0,895 & 0,771 \\
\hline 10. & $a_{2}$ & $b_{5}$ & $\mathrm{C}_{1}$ & $\mathrm{~d}_{2}$ & $\mathrm{e}_{3}$ & $\mathrm{f}_{4}$ & 4 & 3 & 3 & 2 & 3,60 & 3,14 & 27 & 29 & 1,60 & 1,58 & 0,8 & 0,6 & 0 & 0 \\
\hline 11. & $a_{3}$ & $b_{1}$ & $\mathrm{C}_{3}$ & $\mathrm{~d}_{5}$ & $\mathrm{e}_{2}$ & $f_{4}$ & 5 & 5 & 4 & 5 & 4,60 & 4,32 & 76 & 82 & 0,26 & 0,28 & 2,2 & 1,8 & 0,877 & 0,912 \\
\hline 12. & $a_{3}$ & $b_{2}$ & $\mathrm{C}_{4}$ & $\mathrm{~d}_{1}$ & $\mathrm{e}_{3}$ & $f_{5}$ & 5 & 4 & 3 & 4 & 5,04 & 4,71 & 56 & 59 & 0,37 & 0,32 & 0,7 & 1,4 & 0,704 & 0,807 \\
\hline 13. & $a_{3}$ & $b_{3}$ & $C_{5}$ & $\mathrm{~d}_{2}$ & $\mathrm{e}_{4}$ & $f_{1}$ & 5 & 4 & 4 & 4 & 5,11 & 4,62 & 80 & 82 & 0,47 & 0,45 & 6,7 & 6,1 & 0,877 & 0,856 \\
\hline 14. & $a_{3}$ & $b_{4}$ & C1 & $\mathrm{d}_{3}$ & $e_{5}$ & $f_{2}$ & 5 & 5 & 5 & 4 & 5,98 & 5,23 & 107 & 108 & 0,58 & 0,56 & 24,3 & 25,1 & 0 & 0 \\
\hline 15. & $a_{3}$ & $b_{5}$ & $\mathrm{C}_{2}$ & $\mathrm{~d}_{4}$ & $\mathrm{e}_{1}$ & $f_{3}$ & 4 & 4 & 4 & 3 & 7,87 & 7,45 & 67 & 71 & 1,54 & 1,51 & 0,7 & 0,6 & 0,267 & 0,296 \\
\hline 16. & $a_{4}$ & $b_{1}$ & $\mathrm{C}_{4}$ & $\mathrm{~d}_{2}$ & $e_{5}$ & $f_{3}$ & 4 & 3 & 3 & 3 & 6,60 & 6,13 & 109 & 114 & 0,64 & 0,63 & 5,5 & 7,0 & 0,620 & 0,560 \\
\hline 17. & $a_{4}$ & $b_{2}$ & $\mathrm{C}_{5}$ & $\mathrm{~d}_{3}$ & $\mathrm{e}_{1}$ & $\mathrm{f}_{4}$ & 5 & 4 & 4 & 3 & 4,65 & 4,33 & 85 & 95 & 0,27 & 0,28 & 0,8 & 2,0 & 0,877 & 0,773 \\
\hline 18. & $a_{4}$ & $b_{3}$ & $\mathrm{C}_{1}$ & $\mathrm{~d}_{4}$ & $\mathrm{e}_{2}$ & $f_{5}$ & 5 & 4 & 4 & 4 & 3,54 & 3,12 & 138 & 166 & 0,13 & 0,12 & 56,0 & 62,0 & 0 & 0 \\
\hline 19. & $a_{4}$ & $b_{4}$ & $\mathrm{C}_{2}$ & $\mathrm{~d}_{5}$ & $\mathrm{e}_{3}$ & $f_{1}$ & 5 & 4 & 3 & 4 & 4,38 & 4,03 & 134 & 138 & 0,14 & 0,15 & 1,6 & 1,3 & 0,799 & 0,920 \\
\hline 20. & $a_{4}$ & $b_{5}$ & $\mathrm{C}_{3}$ & $\mathrm{~d}_{1}$ & $\mathrm{e}_{4}$ & $f_{2}$ & 4 & 3 & 2 & 1 & 5,42 & 4,93 & 35 & 37 & 2,94 & 2,92 & 0,4 & 0,2 & 0 & 0 \\
\hline 21. & $a_{5}$ & $b_{1}$ & $c_{5}$ & $\mathrm{~d}_{4}$ & $\mathrm{e}_{3}$ & $f_{2}$ & 5 & 4 & 2 & 3 & 2,50 & 2,63 & 61 & 63 & 0,68 & 0,66 & 3,7 & 4,1 & 0 & 0,739 \\
\hline 22. & $a_{5}$ & $b_{2}$ & $\mathrm{C}_{1}$ & $\mathrm{~d}_{5}$ & $\mathrm{e}_{4}$ & $f_{3}$ & 4 & 3 & 1 & 1 & 5,17 & 4,89 & 53 & 66 & 0,74 & 0,73 & 5,9 & 2,9 & 0 & 0 \\
\hline 23. & $a_{5}$ & $b_{3}$ & $\mathrm{C}_{2}$ & $\mathrm{~d}_{1}$ & $\mathrm{e}_{5}$ & $\mathrm{f}_{4}$ & 5 & 4 & 3 & 4 & 4,76 & 4,62 & 44 & 42 & 0,75 & 0,76 & 1,3 & 1,0 & 0,582 & 0,645 \\
\hline 24. & $a_{5}$ & $b_{4}$ & $\mathrm{C}_{3}$ & $\mathrm{~d}_{2}$ & $\mathrm{e}_{1}$ & $f_{5}$ & 4 & 3 & 3 & 2 & 7,17 & 6,79 & 37 & 40 & 2,02 & 1,98 & 0,9 & 1,0 & 0 & 0 \\
\hline 25. & $a_{5}$ & $b_{5}$ & $\mathrm{C}_{4}$ & $\mathrm{~d}_{3}$ & $\mathrm{e}_{2}$ & $f_{1}$ & 3 & 3 & 2 & 2 & 5,90 & 5,22 & 15 & 17 & 1,29 & 1,28 & 0,3 & 0,3 & 0 & 0 \\
\hline
\end{tabular}

Примітки: перші чотири відгуки $\left(\mathrm{y}_{1}-\mathrm{y}_{4}\right)$ описано в попередній публікації [3]; $\mathrm{y}_{5}$ і $\mathrm{y}_{5}^{\prime}-$ характеристика процесу пресування першої і другої серії відповідно, бали; у і і у - зовнішній вигляд першої і другої серії відповідно, бали;

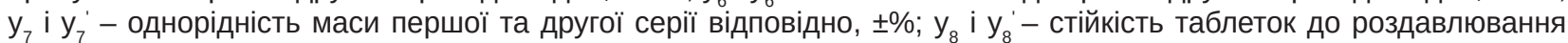
першої та другої серії відповідно, $\mathrm{H} ; \mathrm{y}_{9} \mathrm{i} \mathrm{y}_{9}{ }^{\prime}$ - стираність таблеток першої та другої серії відповідно, \%; $\mathrm{y}_{10} \mathrm{i} \mathrm{y}_{10}$ час розпадання таблеток першої та другої серії відповідно, хв; D i D' - функцція бажаності першої та другої серії відповідно.

ISSN 2312-0967. Pharmaceutical review. 2019. № 3 
Фармацевтична технологія, біофармація, гомеопатія Pharmaceutical technology, biopharmacy, homeopathy

повнювачем у процесі пресування виявилась МКЦ 102 (4,4 бала), якій поступаються: МКЦ 200 (4,2 бала), просолв SMCC 90 (4,2 бала) та просолв EASYtab SP (4,1 бала). Найгірші результати показала МКЦ бурст (3,4 бала).

Серед розпушувачів найкращою дР у процесі пресування $€$ натрію кроскармелоза (4,4 бала), а найгіршою - натрію крохмальгліколят (3,4 бала). Середні результати показали: крохмаль кукурудзяний $(4,2$ бала), крохмаль прежелатинізований (4,2 бала) та натрію карбоксиметилкрохмаль (4,1 бала).

Згідно з одержаними результатами, найкращим сорбентом $€$ неуселін UFL2 (4,6 бала), на другому місці неуселін US2 (4,1 бала), на третьому - аеросил 380 і аеросил 200 (по 3,9 бала). Найменше значення отримав магнію карбонат основний - 3,8 бала.

Після пресування оцінювали зовнішній вигляд таблеток у балах. Групи ДР за важливістю розмістились таким чином: $A>E>B>F>C>D$. Значущими $€$ тільки сорбенти, ковзні речовини та наповнювачі. Найкращим серед сорбентів є неуселін UFL 2 (4,0 бала), а найгірші результати показав магнію карбонат основний (2,3 бала). За допомогою решти сорбентів вдалось одержати таблетки із середніми значеннями, а саме: аеросил 380 - 3,3 бала, неуселін US 2 - 3,1 бала, аеросил 200 - 3,0 бала.

Ковзні речовини, які забезпечують гарний зовнішній вигляд таблеток - це компактрол та Ді-Пак (по 3,5 бала). Їм поступаються такі ДР, як кальцію гідрофросфрат безводний (3,3 бала), емкомпрес (3,0 бала), МагГран (2,4 бала).

Серед наповнювачів перше місце посів просолв SMCC 90 (3,6 бала), на другому - МКЦ 102 і просолв EASYtab SP (по 3,3 бала), на третьому - МКЦ 200 (3,1 бала). Найменшу кількість балів отримали таблетки із МКЦ бурст (2,4 бала).

Ранжований ряд ДР, за результатами визначення однорідності маси виглядає так: $\mathrm{E}>\mathrm{C}>\mathrm{F}>\mathrm{A}>\mathrm{D}>\mathrm{B}$. Серед усіх ковзних речовин тільки таблетки із компактролом та емкомпресом мали однорідність маси в межах $\pm 5 \%$. Інші ДР показали гірші результати, а

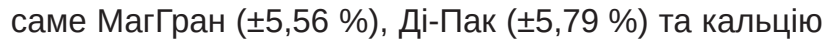
гідрофроссрат $( \pm 6,31 \%)$.

Із групи розпушувачів тільки крохмаль кукурудзяний та крохмаль прежелатинізований дозволяють отримати таблетки з однорідністю маси в межах $\pm 5 \%$. Інші ДР розмістились у такому ранжованому ряді переваг: натрію карбоксиметилкрохмаль $( \pm 5,60 \%)>$ натрію кроскармелоза ( $\pm 5,94 \%)>$ натрію крохмальгліколят ( $\pm 6,10 \%)$.

Серед змащувальних речовин найменшу однорідність маси мали таблетки із натрію стеарилфумаратом ( $\pm 4,55 \%)$, їм поступаються таблетки із магнію стеаратом - $55,06 \%$, кальцію стеаратом $\pm 5,49 \%$, натрію лаурилсульфратом - $\pm 5,64 \%$, кислотою стеариновою $- \pm 5,75 \%$.

За позитивним впливом на однорідність маси таблеток серед досліджених сорбентів на першому міс- ці стоїть неуселін US 2 ( $\pm 4,71 \%)$, який має перевагу над магнію карбонатом основним $( \pm 4,97 \%)$. Таблетки із аеросилом 200, неуселіном UFL 2 та аеросилом 380 мали однорідність маси більше, ніж $\pm 5 \%$.

Із групи наповнювачів тільки МКЦ 102 дозволила отримати таблетки із однорідністю маси в межах $\pm 5 \%$, а саме $\pm 4,96 \%$. Результати інших ДР виглядають так: просолв SMCC 90 ( $\pm 5,20 \%)$, МКЦ 200 $( \pm 5,36 \%)$, просолв EASYtab SP $( \pm 5,41 \%)$, МКЦ бурст $( \pm 5,55 \%)$.

Вплив цукрів на однорідність маси таблеток можна зобразити таким ранжованим рядом: манітол $60( \pm 4,74 \%)>$ мікроцелак $100( \pm 5,11 \%)>$ перлітол 100 SD і перлітол 500 DC (по $\pm 5,54$ \%) > лудіпрес $( \pm 5,56 \%)$.

Також досліджували стійкість таблеток до роздавлювання. Усі групи ДР за значущістю у даному фрармако-технологічному випробуванні розмістились наступним чином: $A>B>E>F>D>C$. Високу стійкість до роздавлювання серед сорбентів показали таблетки із вмістом неуселіну US 2 (105,1 H) та аеросилу 380 (96,2 Н). Найменші показники отримано при дослідженні таблеток із неуселіном UFL 2 (78,8 H), аеросилом 200 (56,2 H) та магнію карбонатом основним $(43,8 \mathrm{H})$.

Серед наповнювачів хорошу стійкість до роздавлювання показали таблетки із МКЦ 200 (96,1 Н), просолвом EASYtab SP (85,3 H), просолвом SMCC 90 $(84,4$ Н) та МКЦ 102 (77,1 Н). Найменш міцними виявились таблетки із вмістом МКЦ бурст $(37,2$ H).

Вплив розпушувачів на стійкість таблеток до роздавлювання можна проілюструвати таким рядом переваг: натрію карбоксиметилкрохмаль $(83,8$ H) > натрію кроскармелоза (82,1 Н) > крохмаль кукурудзяний $(80,5$ H) > крохмаль прежелатинізований $(77,6$ Н) > натрію крохмальгліколят (56,1 H).

Найвищу міцність серед цукрів забезпечує мікроцелак 100 (99,6 H), наступними в ряді речовин $є$ перлітол 100 SD $(76,1 \mathrm{H})$ та лудіпрес $(73,6 \mathrm{H})$, які мають перевагу над перлітолом 500 DC $(68,8$ H) та манітолом $60(62,0 \mathrm{H})$.

Серед ковзних речовин найбільш стійкими до роздавлювання були таблетки, що містили у своєму складі Ді-Пак (97,5 Н). Останній має перевагу над компактролом (90,0 Н), емкомпресом (72,1 Н), кальцію гідрофросфратом безводним $(64,4$ H) та МагГран $(56,1$ H).

Найкращу міцність таблеток серед змащувальних речовин забезпечує магнію стеарат $(95,4$ Н), який має перевагу над кислотою стеариновою $(87,0$ H), натрію лаурилсульфатом (72,5 Н), кальцію стеаратом $(71,9$ H) та натрію стеарилфумаратом $(53,3 \mathrm{H})$.

Наступною досліджували стираність таблеток. У ранжованому ряду групи ДР розмістились таким чином: $A>E>B>C>F>D$. Після проведеного дослідження видимих змін таблеток не виявлено. Найменшу стираність серед сорбентів мають таблетки із неуселіном UFL 2 (0,63 \%) та неуселіном US 2 (0,82 \%),

ISSN 2312-0967. Фармацевтичний часопис. 2019. № 3 
а найбільшу - із аеросил 200 (2,36 \%). Аеросил 380 $(1,05 \%)$ та магнію карбонат основний $(1,09 \%)$ показали середні результати у групі ДР.

Із групи ковзних речовин фрармако-технологічне випробування стираності пройшли тільки таблетки, які містили у своєму складі емкомпрес (0,59 \%), компактрол (0,84 \%) і Ді-Пак (0,85 \%). Найбільше значення стираності отримано із кальцію гідрофоссратом безводним (1,50 \%) і МагГраном (2,17\%).

Наповнювачі впливають на показник стираності таблеток наступним чином. Найменшу стираність забезпечує МКЦ 102 (0,65 \%), який має перевагу над МКЦ 200 (0,79\%), просолвом SMCC 90 (0,83\%). Дане випробування не пройшли таблетки із просолвом EASYtab SP (1,83 \%) та МКЦ бурстом (1,86 \%).

Серед вивчених розпушувачів найменше значення стираності таблеток забезпечував крохмаль прежелатинізований $(0,72 \%)$, за ним розташувався - крохмаль кукурудзяний (0,84 \%). Таблетки, які містили у своєму складі натрію кроскармелозу (1,04 \%), натрію карбоксиметилкрохмаль $(1,16 \%)$ та натрію крохмальгліколят (2,20 \%) дане випробування не пройшли.

Серед цукрів тільки лудіпрес дозволив отримати таблетки, які відповідали вимогам ДФУ, із значенням стираності - 0,58 \%. Таблетки із манітолом 60 (1,09\%), перлітолом 100 SD (1,13\%), перлітолом 500 DC (1,39 \%) та мікроцелаком 100 (1,77\%) випробування стираності не пройшли.

Найменшу стираність таблеток серед змащувальних речовин забезпечує кислота стеаринова (0,67 \%), яка має перевагу над магнію стеаратом (0,68 \%) та натрію лаурилсульфратом (0,99%). Дане випробування не пройшли таблетки із кальцію стеаратом $(1,79 \%)$ та натрію стеарилсумаратом (1,82 \%).

Потім таблетки досліджували на розпадання. Групи ДР розмістились у ранжованому ряду наступним чином: $\mathrm{C}>\mathrm{E}>\mathrm{D}>\mathrm{B}>\mathrm{A}>\mathrm{F}$. Серед розпушувачів найшвидше розпадались таблетки із натрію кроскармелозою (0,9 хв). Приблизно однаковий результат показали таблетки із натрію крохмальгліколятом (2,69 хв), натрію карбоксиметил крохмалем (3,61 хв) та крохмалем прежелатинізованим (4,71 хв). Найдовше розпадались таблетки із крохмалем кукурудзяним $(18,42$ хв).

Ранжований ряд переваг для сорбентів за їх впливом на розпадання таблеток має такий вигляд: аеросил 200 (1,72 хв) > магнію карбонат основний $(2,14$ Хв) > аеросил $380(5,83$ Хв) > неуселін UFL 2 $(6,96$ хв) > неуселін US 2 (13,68 хв).

Серед наповнювачів найшвидше розпадались таблетки із МКЦ бурстом (1,02 хв). Дещо повільніше розпадались таблетки, що містили у своєму складі МКЦ 102 (3,24 хв), МКЦ 200 (4,13 хв), які мають перевагу над просолвом EASYtab SP (7,19 хв) і просолвом SMCC 90 (14,75 хв).

Досліджуючи групу ДР цукрів, можна зробити висновок, що найшвидше розпадались таблетки із ма-
Фармацевтична технологія, біофармація, гомеопатія

Pharmaceutical technology, biopharmacy, homeopathy

нітолом 60 (2,90 хв), перлітолом 500 DC (2,96 хв) і перлітолом 100 SD (3,34 хв), а найповільніше із - лудіпресом (5,73 хв) та мікроцелаком 100 (15,40 хв).

Вплив ковзних речовин на розпадання таблеток із рослинними екстрактами та ефрірною олією можна зобразити таким ранжованим рядом: емкомпрес $(1,72$ хв) > кальцію гідросросфрат безводний = МагГран $(2,40$ хв) > Ді-Пак $(9,71$ хв) > компактрол $(14,1$ XB).

Серед ковзних речовин найшвидше розпадались таблетки із натрію стеарилорумаратом (1,02 хв). Середні результати показали таблетки із кислотою стеариновою (4,30 хв), магнію стеаратом (4,95 хв) та кальцію стеаратом (7,02 хв). Найдовше розпадались таблетки із натрію лаурилсульфатом (12,98 хв).

Проведені дослідження дозволили встановити вплив 30 рівнів фракторів на основні фрармако-технологічні показники таблеток. За кожним відгуком отримували ряди переваг, які в більшості випадків мають в якості «лідерів» різні ДР. Тому було вирішено для вибору кращих ДР використати узагальнений показник якості - фрункцію бажаності [5]. За допомогою шкали первинні результати за деякими вивченими відгуками $\left(\mathrm{y}_{5}-\mathrm{y}_{10}\right)$ переводили в безрозмірні значення. Дисперсійний аналіз результатів, отриманих за допомогою фрункції бажаності дозволив побудувати такий ряд переваг фракторів: $F>B>C>A>D>E$.

Із групи змащувальних речовин кращі результати фрункції бажаності було отримано при використанні магнію стеарату $(0,59)$ і кислоти стеаринової $(0,50)$, яким поступаються натрію стеарилфумарат $(0,46)$, натрію лаурилсульфат $(0,25)$ і кальцію стеарат $(0,02)$.

За впливом на узагальнений показник наповнювачі можна розмістити таким чином: МКЦ $102(0,59)>$ просолв SMCC $90(0,46)>$ МКЦ $200(0,45)>$ просолв EASYtab SP $(0,34)>$ МКЦ бурст $(0,06)$.

Серед розпушувачів найбільше значення фрункції бажаності отримували при використанні крохмалю прежелатинізованого $(0,56)$. Інші ДР показали менше значення даного показника, а саме: натрію карбоксиметилкрохмаль $(0,48)$, натрію кроскармелоза $(0,45)$, натрію крохмальгліколят $(0,27)$, крохмаль кукурудзяний $(0,11)$.

Ранжований ряд переваг ДР із групи сорбентів має такий вигляд: неуселін UFL $2(0,56)>$ неуселін US 2 $(0,46)>$ аеросил $380(0,41)>$ аеросил $200(0,27)>$ магнію карбонат основний $(0,19)$.

Серед цукрів найбільше значення функції бажаності спостерігали в таблеток із манітолом $60(0,55)$ і лудіпресом $(0,43)$. Гірші показники показали: перлітол 100 SD $(0,35)$, перлітол 500 DC $(0,29)$, мікроцелак $100(0,26)$.

Найкращі характеристики за впливом на фрункцію бажаності серед ковзних речовин мав емкомпрес $(0,56)$, за ним стоїть Ді-Пак $(0,38)$, компактрол $(0,35)$, а також кальцію гідрофросфат безводний $(0,33)$; на останньому місці - МагГран $(0,27)$.

ISSN 2312-0967. Pharmaceutical review. 2019. № 3 
Фармацевтична технологія, біофармація, гомеопатія Pharmaceutical technology, biopharmacy, homeopathy

Висновки. 1. Проведені дослідження дозволили встановити вплив 30 рівнів фракторів на основні фрармако-технологічні показники таблеток із сухими екстрактами трави герані сибірської, герані криваво-червоної та ефрірної олії шавлії мускатної.

2. За кожним відгуком побудовано ранжовані ряди переваг впливу ДР на 6 відгуків (показників) таблеток із рослинними екстрактами та ефрірною олією.
3. На основі отриманих результатів обрано кращі ДР для розробки складу і технології таблетованого фрітозасобу для місцевого застосування у ротовій порожнині, а саме: неуселін UFL 2, неуселін US 2, МКЦ 102, натрію кроскармелоза, крохмаль прежелатинізований, манітол 60, лудіпрес, емкомпрес, магнію стеарат.

Конфолікт інтересів: відсутній.

Conflicts of interest: authors have no conflict of interest to declare.

\section{SUBSTANTIATION OF SELECTION OF EXCIPIENTS FOR OBTAINING TABLETS WITH PLANT EXTRACTS AND ESSENTIAL OIL}

\section{O. I. Hordiienko, T. A. Hroshovyi}

\section{Horbachevsky Ternopil National Medical University hordiienko.oi@gmail.com}

The aim of the work. Investigate and select the optimal excipients into the composition of tablets based on dried extracts herbs of Geranium sanguineum L., Geranium sibiricum L. and essential oil of Salvia sclare for local application in the oral cavity.

Materials and Methods. The composition of tablets includes a pharmaceutical composition containing dry extracts herbs of Geranium sanguineum L. and Geranium sibiricum L., essential oil of Salvia sclare, and also excipients. The influence of excipients on the pharmaco-technological properties of the tablets was studied by the indicators: the pressing process, the appearance of tablets, the uniformity of mass, resistance to crushing of tablets, friability, time of disintegration.

Results and Discussion. The results of the dispersion analysis of experimental data showed that the process of pressing tablets with microcrystalline cellulose (MCC) 102, sodium croscarmellose and neusilin UFL 2 proceeded uniformly, without adhesion of the powder masses to the press tool. The tablets with neusilin UFL 2, compactrol, DI-PAC and prosolv SMCC 90 had the best appearance.

The uniformity of mass within $\pm 5 \%$ provided the following excipients: compactrol, emcompress, corn starch, pregelatinized starch, sodium stearyl fumarate, basic magnesium carbonate, MCC 102, mannitol 60.

The tablets with highest resistance to crushing were able to get with neusilin US 2, MCC 200, sodium carboxymethyl starch, microcelac 100, DI-PAC and magnesium stearate.

Neusilin UFL 2, emcompress, MCC 102, pregelatinized starch, ludipress and stearic acid allowed to obtain the tablets with the least friability. The tablets with sodium croscarmellose, aerosil 200, MCC burst, mannitol 60 , emcompress and sodium stearyl fumarate were disintegrated the fastest.

Conclusions. The influence of 30 excipients on the pharmaco-technological properties of tablets with plant extracts and essential oil were studied. According to the totality of the studied indices, the best combination of excipients for further study was selected in order to develop the optimal composition and technology of the tablets for topical application in the oral cavity.

Key words: tablets; plant extracts; excipients; pharmaco-technological indicators; mathematical planning.

\section{ОБОСНОВАНИЕ ВЫБОРА ВСПОМОГАТЕЛЬНЫХ ВЕЩЕСТВ ДЛЯ ПОЛУЧЕНИЯ ТАБЛЕТОК С РАСТИТЕЛЬНЫМИ ЭКСТРАКТАМИ И ЭФИРНЫМ МАСЛОМ}

\section{О. И. Гордиенко, Т. А. Грошовый}

Тернопольский национальный медицинский университет имени И. Я. Горбачевского Моз Украины hordiienko.oi@gmail.com

Цель работы. Исследовать и выбрать оптимальные вспомогательные вещества (BВ) в состав таблеток на основе сухих экстрактов травы герани кроваво-красной, герани сибирской и эфирного масла шалфея мускатного для местного применения в полости рта.

Материалы и методы. В состав таблеток входит фрармацевтическая композиция, содержащая сухие экстракты травы герани кроваво-красной и герани сибирской, эфирное масло шалфея мускатного, а также ВВ. Влияние ВВ на

ISSN 2312-0967. Фармацевтичний часопис. 2019. № 3 
фрармако-технологические свойства таблеток изучали по следующим показателям: процесс прессования, внешний вид, однородность массы, устойчивость к раздавливанию, стираемость, время распада.

Результаты и обсуждение. Результаты дисперсионного анализа экспериментальных данных показали, что процесс прессования таблеток с МКЦ 102, натрия кроскармеллозой и неусилином UFL 2 проходил равномерно, без адгезии порошковых масс к пресс-инструменту. Таблетки с неусилином UFL 2, компактролом, Ди-Пак и просолвом SMCC 90 имели лучший внешний вид.

Однородность массы таблеток в пределах \pm 5\% обеспечивали следующие ВВ: компактрол, эмкомпрес, крахмал кукурузный и прежелатинизированный, натрия стеарилсумарат, магния карбонат основной, МКЦ 102, маннитол 60. Устойчивые к раздавливанию таблетки удалось получить с помощью неусилина US 2, МКЦ 200, натрия карбоксиметилкрахмала, микроцелака 100, Ди-Пак и магния стеарата.

Неусилин UFL 2, емкомпрес, МКЦ102, крахмал прежелатинизированный, лудипрес и стеариновая кислота позволили получить таблетки с наименьшей стираемостю, а быстрее распадались таблетки с натрия кроскармелозой, аэросилом 200, МКЦ бурст, маннитолом 60, емкомпресом и натрия стеарилфумаратом.

Выводы. Изучено влияние 30-ти ВВ на фрармако-технологические свойства таблеток с растительными экстрактами и эсрирным маслом. По совокупности изученных показателей отобраны лучшие сочетания ВВ для дальнейшего изучения с целью разработки оптимального состава и технологии таблеток для местного применения в полости рта.

Ключевые слова: таблетки; растительные экстракты; вспомогательные вещества; фрармако-технологические показатели; математическое планирование.

\section{Список літератури}

1. Пат. 131363 України: МПК А61K 36/00, А61K 36/537, A61K 47/46, A61P 31/00. Фармацевтична композиція 3 антимікробною, протигрибковою і протизапальною дією на основі рослинних екстрактів та ефрірної олії / Гордієнко О. І., Грошовий Т. А., Климнюк С. І., Покришко О. В., Бензель І. Л., Бензель Л. В. № u201807941 ; заявл. 16.07.2018 ; опубл. 10.01.2019, Бюл. № 1.

2. Допоміжні речовини у виробництві ліків: навч. посіб. для студентів вищ. фрармац. навч. закл. / [О. А. Рубан, І. М. Перцев, С. А. Куценко та ін.]. - Харків : Золоті сторінки, 2016. - 720 с.

3. Гордієнко О. І. Дослідження впливу допоміжних речовин на фрармако-технологічні властивості порошкових мас із рослинними екстрактами та ефрірною олією / О.І.Гордієнко, Т. А. Грошовий // Фармацевтичний часопис. - 2019. - № 2. - С. 36 42.

4. Державна Фармакопея України: в 3 т. / Державне підприємство «Український науковий срармакопейний центр якості лікарських засобів». - 2-е вид. - Харків: Державне підприємство «Український науковий фармакопейний центр якості лікарських засобів», 2015. - T. 1. - 1128 c.

5. Математичне планування експерименту при проведенні наукових досліджень в фрармації / [Т. А. Грошовий, В. П. Марценюк, Л. І. Кучеренко та ін.]. - Тернопіль : Укрмедкнига, 2008. - 367 с.

\section{References}

1. Hordiienko OI, Hroshovyi TA, Klymniuk SI, Pokryshko OV, Benzel IL, Benzel LV, inventors; I. Horbachevsky Ternopil National Medical University, assignee. Pharmaceutical composition with antimicrobial, antifungal and anti-inflammatory action on the basis of plant extracts and essential oil [Фармацевтична композиція 3 антимікробною, протигрибковою і протизапальною дією на основі рослинних екстрактів та ефрірної олії]. UA 201807941 (Patent) 2019 Jan 10. Ukrainian.

2. Ruban OA, Pertsev IM, Kutsenko SA, Maslii YuS. Substances in the manufacture of drugs: teaching manual for students of higher education [Допоміжні речовини у виробництві ліків: навч. посіб. для студентів вищ. фрармац. навч. закл.] Kharkiv: Zoloti storinky; 2016. Ukrainian.

3. Hordiienko OI, Hroshovyi TA [Investigation of the influence of excipients on pharmaco-technological properties of powder masses with plant extracts and essential oil]. Farmatsevt chasop. 2019;2: 3642. Ukrainian.

4. State Pharmacopoeia of Ukraine. [Державна Фармакопея України: в 3 т.,2е вид.] Kharkiv: Derzhavne pidpryiemstvo "Naukovoekspertnyi farmakopeinyi tsentr"; 2015. Ukrainian.

5. Hroshovyi TA, Martseniuk VP, Kucherenko LI, Vronska LV, Hurieieva SM. Mathematical planning of experiment in pharmacy. [Математичне планування експерименту при проведенні наукових досліджень в фрармації] Ternopil: Ternopil State Medical University; 2008. Ukrainian. 
Фармацевтична технологія, біофармація, гомеопатія

Pharmaceutical technology, biopharmacy, homeopathy

\section{Відомості про авторів:}

Гордієнко О. І. - викладач фрармацевтичних дисциплін, Чортківський державний медичний коледж; аспірант кафедри управління та економіки фрармації з технологією ліків, Тернопільський національний медичний університет імені І. Я. Горбачевського, Тернопіль, Україна. E-mail: hordiienko.oi@gmail.com, ORCID 0000-0001-7809-2871

Грошовий Т. А. - д. фрармац. н., професор, завідувач кафедри управління та економіки фрармації 3 технологією ліків, Тернопільський національний медичний університет імені І. Я. Горбачевського, Тернопіль, Україна. E-mail: grochovuy@ukr.net, ORCID 0000-0002-6427-2158

Information about the authors:

Hordiienko O. I. - teacher of pharmaceutical disciplines, Chortkiv State Medical College; PhD-student of Pharmacy Management, Economics and Technology Department, I. Horbachevsky Ternopil National Medical University, Ternopil, Ukraine. E-mail: hordiienko.oi@gmail.com, ORCID 0000-0001-7809-2871

Hroshovyi T. A. - DS (Pharmacy), Professor, Chief of the Department of Pharmacy Management, Economics and Technology, I. Horbachevsky Ternopil National Medical University, Ternopil, Ukraine. E-mail: grochovuy@ukr.net, ORCID 00000002-6427-2158 